\title{
Rhizobium Strain Influence on Disruption of Clover Nodule Development at High Root Temperature
}

\author{
By C. E. PANKHURST \\ Botany Department, Australian National University, Canberra, Australia \\ AND A. H. GIBSON \\ Division of Plant Industry, CSIRO, Canberra, A.C.T., Australia
}

(Received I4 July 1972; revised I I September 1972)

\begin{abstract}
SUMMAR Y
Trifolium subterraneum plants grown at $30{ }^{\circ} \mathrm{C}$ root temperature nodulated 3 days after inoculation with Rhizobium trifolii and nitrogenase activity (determined by acetylene-reduction) was detected 3 days later. While all four strains of $R$. trifolii examined formed effective nodules at $22{ }^{\circ} \mathrm{C}$, at $30^{\circ} \mathrm{C}$ only the nodules formed by strain TAI showed a rapid increase in nitrogenase activity. Light and electron microscopy of the nodules formed by one temperature-sensitive strain (NA30) showed the following abnormalities: multiple branching and distortion of the infection threads; failure of many bacteria to develop into characteristic bacteroids; continued division of these bacteria to give atypical multiple occupancy of the membrane envelopes; release of polysaccharide from ruptured infection threads into the host cytoplasm; rapid degeneration of the membrane envelopes and their contents. While the development of the membrane envelopes appeared to be under host control, the effect of the higher temperature on bacteroid development was highly strain specific.

Upon transfer of nodulated plants from 22 to $30^{\circ} \mathrm{C}$, bacteroid tissue in nodules formed by the temperature-sensitive strain NA30 broke down rapidly but nodules formed by strain TAI were less severely affected.
\end{abstract}

\section{INTRODUCTION}

Root temperature has a marked influence on the development and function of the legumeRhizobium symbiosis. The infection of the root hairs, the rate of nodule appearance, the number of nodules formed, the amount and rate of nitrogen fixation, and the distribution of fixed nitrogen from the nodules are affected by root temperature (see review by Gibson, I97I). Relatively little is known of the effects of root temperature on the structure of the nodules, or on the development of the bacteroid (or nitrogen-fixing) tissue within them.

Dart \& Mercer (I965) showed that nodules formed on the tropical legume Vigna sinensis, grown at $2 \mathrm{I}{ }^{\circ} \mathrm{C}$ (a low temperature for this host), contained a low proportion of infected cells and large quantities of starch in the uninfected cells. At the highest temperature examined, $36{ }^{\circ} \mathrm{C}$, a high proportion of the cells were infected (as at 24 to $33{ }^{\circ} \mathrm{C}$ ) and starch deposits, largely absent from cells in the middle of the temperature range, were again evident in the uninfected cells. In nodules formed on Trifolium subterraneum grown at suboptimal root temperatures, Roughley ( 1970 ) found that the rate of development, and subsequent degeneration of the bacteroid tissue at 7 and I I ${ }^{\circ} \mathrm{C}$ was greatly slowed relative to that at $19{ }^{\circ} \mathrm{C}$. At the lower temperature, a greater volume of active tissue finally developed, in apparent compensation for the lower nitrogen fixing activity/unit tissue. 
Previous studies showed a specific effect of high root temperatures on nitrogen fixation by Trifolium subterraneum nodulated by some strains of Rhizobium trifolii. Plants grown at $22{ }^{\circ} \mathrm{C}$ following inoculation with either strain TAI or NA30 formed effective nodules whereas at $30^{\circ} \mathrm{C}$ only the nodules produced by strain TA I fixed adequate nitrogen for plant growth (Gibson, 1967). The transfer of plants nodulated at $22{ }^{\circ} \mathrm{C}$ to a root temperature of $30{ }^{\circ} \mathrm{C}$ resulted in a marked decrease in nitrogen fixation by the NA30 nodulated plants; the reduction in fixation was proportional to the length of daily exposure to $30{ }^{\circ} \mathrm{C}$ (Gibson, 1969).

This paper examines the effects of high root temperature on the development and maintenance of nitrogenase activity by plants inoculated with Rhizobium trifolii strains. Lightand electron-microscope studies of changes in nodule structure and bacteroid development are described.

\section{METHODS}

Bacterial strains. The strains used were TAI (isolated from Trifolium subterraneum, Bridport, Tasmania), NA30 (T. repens, Kempsey, N.S.W., Australia), CC2480a (T. subterraneum, Yannina, Greece) and wU95 ( $T$. subterraneum, Western Australia).

Plant culture. The host was Trifolium subterraneum cv. Tallarook (F. H. Brunning Pty. Ltd, Melbourne, Australia). The plants were grown with the roots on agar slopes inside test tubes capped with Al-foil, and with the shoots free above the tubes (Gibson, 1963). The seedlings were inoculated with 3-day cultures of Rhizobium trifolii 3 days after sowing and grown at 22 or $30^{\circ} \mathrm{C}$ root temperature, with a $22 / 15{ }^{\circ} \mathrm{C}$ shoot temperature regime based on a I4 h daily light period. Light intensity was $2500 \mathrm{ft}$-candles from a mixture of incandescent and fluorescent lights (Gibson, I965).

Nodules were removed for structural studies I, 3, 5, 8 and Io days after their first appearance and 2, 3, 4 and 6 days after transfer from 22 to $30^{\circ} \mathrm{C}$ root temperature. At the same time, nitrogenase activity was determined by the acetylene-reduction technique (see below).

Light microscopy. Serial microtome sections ( 6 to $8 \mu \mathrm{m}$ ) were cut from paraffin-embedded nodules and stained with Heidenhain's haematoxylin and safranin. For detailed study of individual cells, sections I $\mu \mathrm{m}$ thick were cut from material fixed and embedded in glycolmethacrylate (Feder \& O'Brien, I968) and stained with $0.05 \%$ toluidine blue in acetate buffer, $\mathrm{pH} 4{ }^{\circ} \mathrm{O}$. The periodic acid-Schiff reaction (Jensen, I962) was used as a test for polysaccharide material.

Electron microscopy. Nodule tissue was fixed in $3 \%$ glutaraldehyde in 0.025 M-phosphate buffer, $\mathrm{pH} 7 \cdot 0$, for $2 \mathrm{~h}$, washed in three changes of the same buffer for $\frac{1}{2} \mathrm{~h}$, and then treated with $2 \%$ osmium tetroxide in $0.025 \mathrm{M}$-phosphate buffer, $\mathrm{pH} 7 \cdot 0$, for $\mathrm{I} \frac{1}{2} \mathrm{~h}$. The tissues were then dehydrated in ethanol and infiltrated with Epon through propylene oxide. Embedding was done under vacuum and the blocks were polymerized at $85^{\circ} \mathrm{C}$ for $24 \mathrm{~h}$. Thin sections were cut with glass knives, on a LKB 'Ultratome', stained with saturated uranyl acetate in $50 \%$ ethanol followed by lead citrate, and examined in a Philips EM 200 electron microscope at $80 \mathrm{kV}$.

Nodule measurements. An estimate of the number of bacteroids/membrane envelope, and the profile area of envelopes, and of bacteroids, was obtained from electron micrographs by cutting out the profiles and weighing them. Areas were then determined from the weight/ area ratio of the paper and from the photographic magnification. Estimates of the degree of infected tissue degenerating in nodules after transfer from the lower to the higher root temperature were made from similar measurements from light micrographs.

Acetylene-reduction by nodulated root systems. Nitrogenase activity was determined by the 


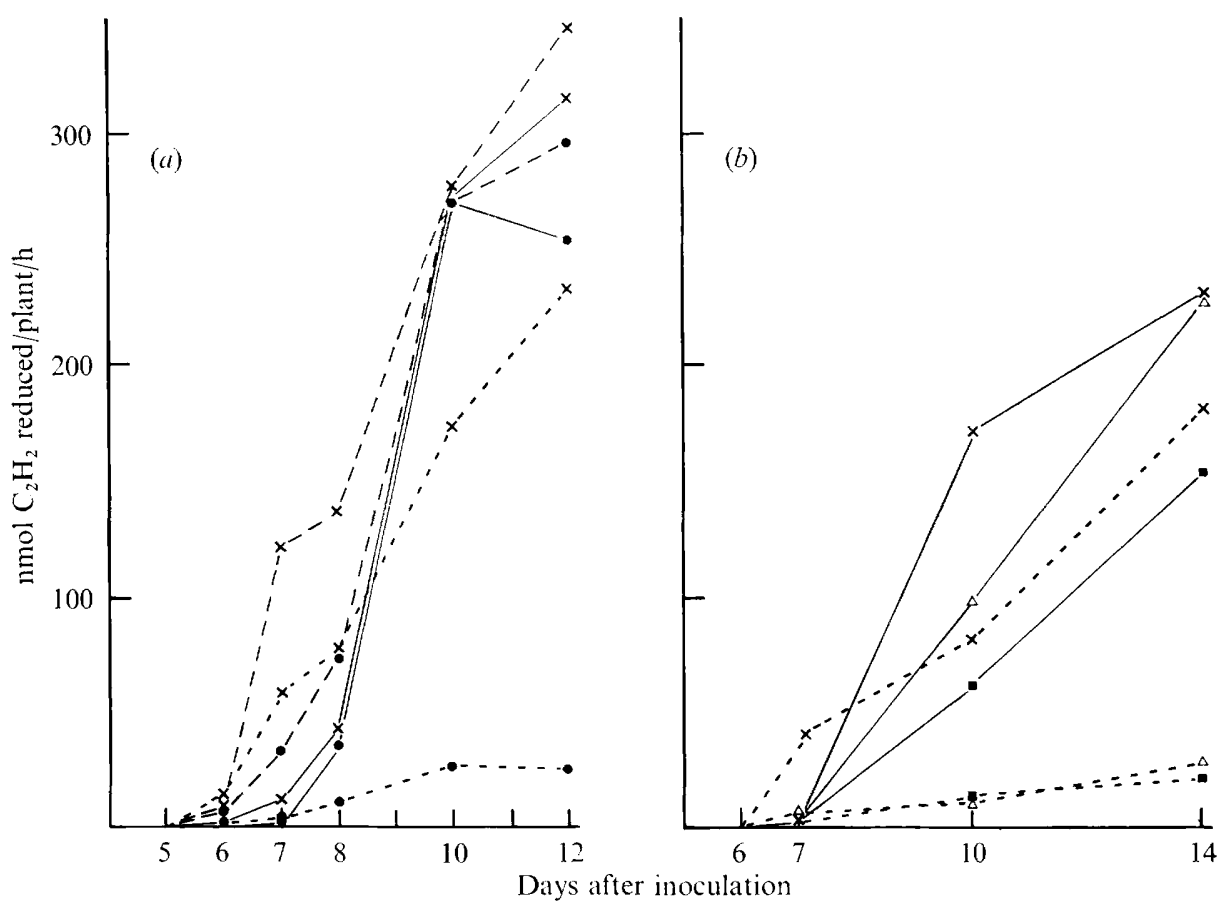

Fig. I. Increase in nitrogenase activity of Trifolium subterraneum plants inoculated with (a) Rhizobium trifolii strains TAI $(\times)$ and NA30 $(O)$ and $(b)$ strains TAI $(\times), \operatorname{CC2480a~}(\triangle)$ and WU95 (ם)

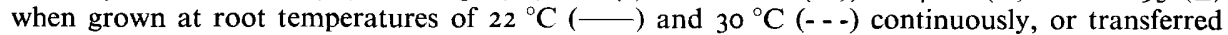
from 30 to $22{ }^{\circ} \mathrm{C} 2$ days after inoculation (- -). Activity determined by acetylene-reduction technique.

acetylene-reduction assay (Hardy, Holsten, Jackson \& Burns, 1968). Blotted nodulated roots (in pairs) were put into 13.5 or $40 \mathrm{ml}$ rubber-capped glass vials. The vials were evacuated and filled with a gas mixture of $\mathrm{O}_{2}, \mathrm{C}_{2} \mathrm{H}_{2}$ and $\mathrm{Ar}(\mathrm{I}: \mathrm{I}: 3)$ at atmospheric pressure, then incubated at $22{ }^{\circ} \mathrm{C}$ or $30{ }^{\circ} \mathrm{C}$ for 30 to $60 \mathrm{~min}$. Analysis of $\mathrm{C}_{2} \mathrm{H}_{2}$ and $\mathrm{C}_{2} \mathrm{H}_{4}$ was done with a Philips P 4000 gas chromatograph (Bergersen, 1970).

Growth rate of the two strains. Cultures of two strains (TAI and NA30) were grown in $\mathrm{I} 00 \mathrm{ml}$ of a modified Bergersen's (I96I) liquid medium (in $\mathrm{g} / \mathrm{l}:$ mannitol, $4 \cdot 0$; glucose, $\mathrm{I} \cdot 0$; Na-glutamate, 0.25 ; yeast extract, $\mathrm{I} \cdot 0$ ) in $250 \mathrm{ml}$ flasks with rotary agitation (I $20 \mathrm{rev} . / \mathrm{min}$ ) in temperature-controlled incubators. Inocula were adjusted to give the same starting optical density (read at $600 \mathrm{~nm}$ on a Unicam SP600) and readings were made every $4 \mathrm{~h}$ until the stationary growth phase was reached.

\section{RESULTS}

Nitrogenase activity and structural development of young nodules

Nitrogenase activity was first detected by the acetylene-reduction technique 6 days after inoculation ( 3 days after nodules were recognized) (Fig. I $a$ ). During the following 6 days, activity reached a high level in the nodules of all plants grown at $22^{\circ} \mathrm{C}$, and in the nodules of TAI plants grown at $30^{\circ} \mathrm{C}$. However, activity remained at a low level in the plants inoculated with NA30, wU95, or $\mathrm{CC} 2480 a$ and grown at $30{ }^{\circ} \mathrm{C}$ (Fig. I). The acetylene-reducing activity of NA30 plants transferred from 30 to $22{ }^{\circ} \mathrm{C} 2$ days after inoculation was detected earlier than 
that of plants grown continuously at $22{ }^{\circ} \mathrm{C}$ but increased at a rate similar to that of these controls. The amounts of nitrogen fixed to day $\mathbf{2} 2$ were in accord with the acetylene-reduction data.

Development of nodules at $22^{\circ} \mathrm{C}$. Nodules formed by strains TAI and NA3O appeared 4 to 6 days after inoculation, and development proceeded normally. Apical meristem, bacteroidcontaining zone, cortex and vascular traces were clearly defined 3 days after the nodules appeared. Fig. 2(a) shows the gross structure of an 8-day-old NA30 nodule. Mature infected host cells have a large central vacuole with bacteroids packed into the surrounding cytoplasm. The oval or pear-shaped bacteroids were 8 to Io times the size of vegetative bacteria, and each was enclosed within a membrane envelope considered to be derived from the host cell plasmalemma during bacterial release from the infection threads (Goodchild $\&$ Bergersen, 1966; Dixon, 1967). Amyloplasts were usually present around the periphery of the bacteroidcontaining cells, and many mitochondria could be seen adjacent to them (Fig. $2 c$ ).

Development of nodules at $30^{\circ} \mathrm{C}$. The early development of TAI nodules at $30{ }^{\circ} \mathrm{C}$ (until they were 8 days old) was identical to that of the nodules at $22{ }^{\circ} \mathrm{C}$. Nodules formed by NA30 developed normally until they were 2 to 3 days old, but severe disruption of development then occurred. Fig. $2(b)$ shows the general features of an 8-day-old NA30 nodule formed at $30{ }^{\circ} \mathrm{C}$. The following abnormal features were found:

(i) Many of the bacteria released into the host cells failed to develop into normal bacteroids. Instead they apparently continued division within the envelopes as each enclosed two, four, six or more bacteria (Fig. $2 d, 3 a$ ). These bacteria had undergone little or no enlargement (average profile area $0.49 \mu \mathrm{m}^{2}$, cf. $0.45 \mu \mathrm{m}^{2}$ for vegetative NA3O in the infection threads), and were approximately one-seventh the size of NA30 bacteroids in nodules formed at $22{ }^{\circ} \mathrm{C}$ (Table I; Fig. $3 a, b$ ). However, the membrane envelopes formed at $30^{\circ} \mathrm{C}$ had approximately the same profile area as those found at $22{ }^{\circ} \mathrm{C}$ (Table $\mathrm{I}$ ). The envelopes at $30{ }^{\circ} \mathrm{C}$ fragmented and degenerated very rapidly (Fig. $3 c$ ) and released the bacteria into the host cell cytoplasm (Fig. $3 d$ ). Recognizable structure was rapidly replaced by many granular bodies within the cytoplasm.

(ii) Infection threads showed increased ramification into the newly differentiated host cells with two or three threads releasing bacteria into the one cell. These infection threads showed increased branching and a distorted shape (Fig. 4a) when compared with normal infection threads.

(iii) Some infected cells in the centre of the nodules were filled with material giving a positive periodic acid-Schiff reaction for polysaccharide, and in older cells, towards the base of the nodules, the entire cell vacuole was filled with this material. In electron micrographs, the material in the vacuoles was electron-dense and contained many small granules (Fig. $4 b$ ). It frequently had a fibrous texture and appeared to originate from the disruption of infection threads (Fig. 4c) rather than from the breakdown of the membrane envelopes. The positive tests for polysaccharide in sections examined by light microscopy suggest that this material may be polysaccharide. Many bacteria within this polysaccharide were inflated to abnormal size (profile area up to $10 \mu \mathrm{m}^{2}$; Fig. $4 b, d$ ) and eventually appeared to burst. This could be due either to inability to divide or to osmotic swelling.

Older nodules formed by TAI ( 8 to Io days old) showed some of the above abnormalities. Membrane envelopes containing two, four or six bacteria were occasionally found among normal bacteroids (Fig. 5a; Table I) and some cells appeared to be undergoing premature degeneration. 

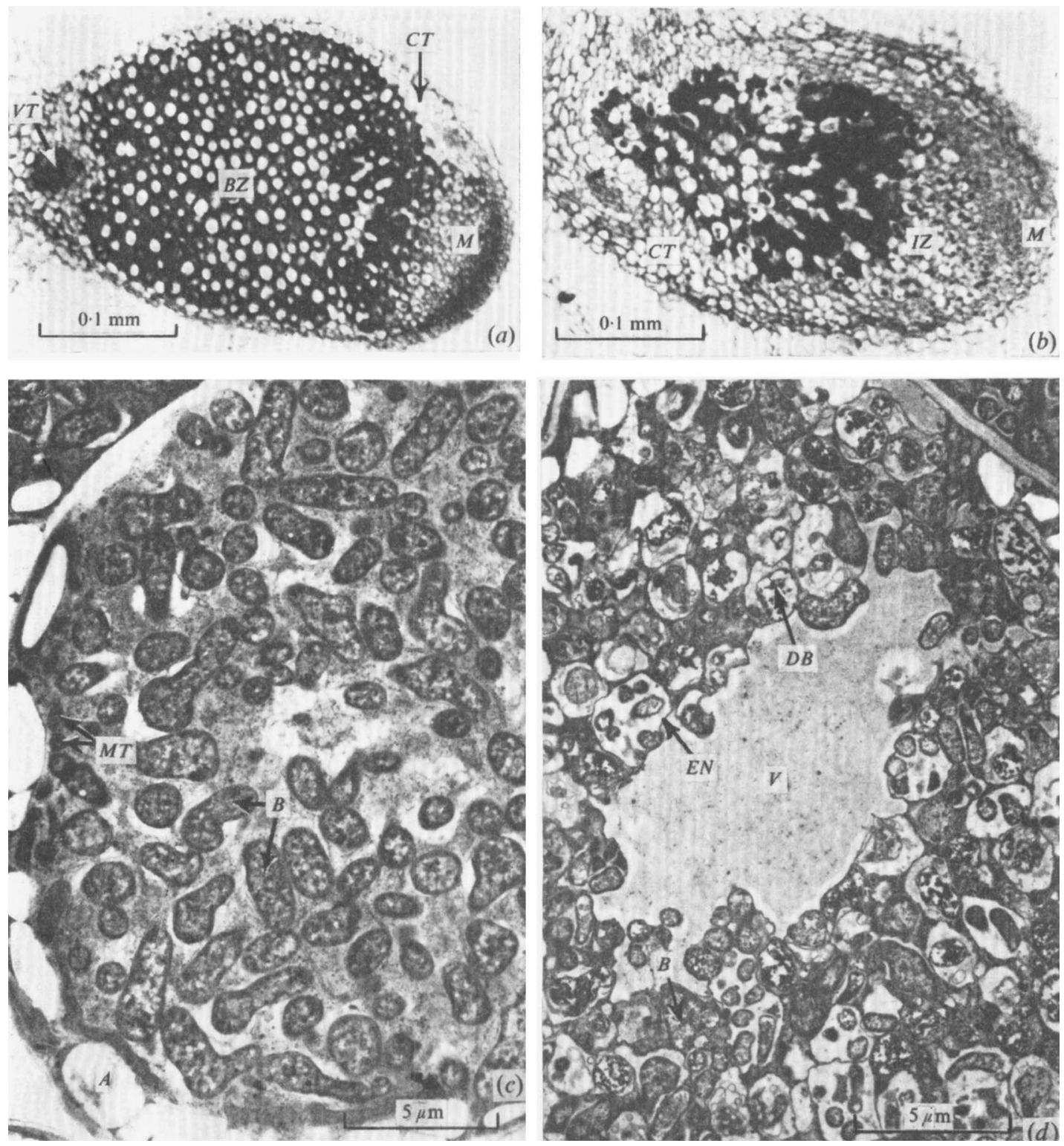

Fig. 2. (a) A longitudinal section of an 8-day-old nodule formed by NA3O at $22^{\circ} \mathrm{C}$, showing meristem $(M)$, central zone containing mature bacteroids $(B Z)$, external cortex $(C T)$ and vascular traces $(V T)$.

(b) A longitudinal section of an 8-day-old nodule formed by NA30 at $30^{\circ} \mathrm{C}$, showing an extensive zone of infection thread penetration $(I Z)$ and a disorganized bacteroid-containing zone.

(c) A section of a mature bacteroid-containing cell in an 8-day-old nodule formed by NA30 at $22{ }^{\circ} \mathrm{C}$, showing swollen bacteroids $(B)$, and many amyloplas's $(A)$ with mitochondria $(M T)$ adjacent to them.

(d) A section of a mature cell from the central zone of an 8-day-old nodule formed by NA30 at $30{ }^{\circ} \mathrm{C}$. Note the almost uniform occurrence of several bacteria/host membrane envelope, and the occasional normal-appearing bacteroids. Many of the bacteria appear to be undergoing degeneration $(D B)$, and breaking up into small electron-dense granules. $V$, Vacuole; $E N$, enclosing membrane envelope. 

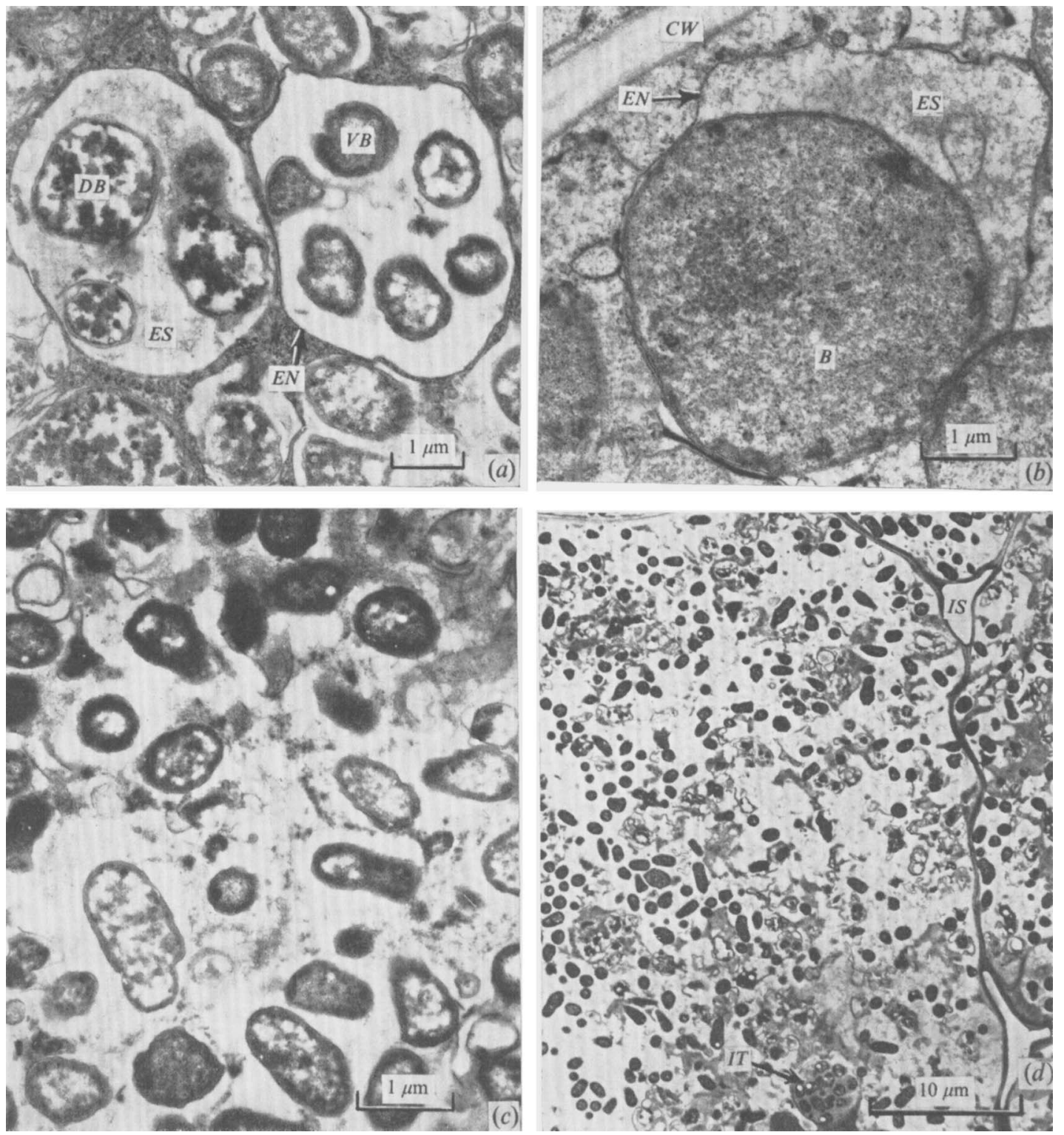

Fig. 3. (a) Host membrane envelopes containing several bacteria, in a nodule formed by NA30 at $30^{\circ} \mathrm{C}$. $V B$, Vegetative bacterium; $E S$, envelope enclosed space; $D B$, degenerating bacterium.

$(b)$ A single mature bacteroid $(B)$ enclosed within a single membrane envelope $(E N)$, in a nodule formed by Na30 at $22{ }^{\circ} \mathrm{C}$. $C W$, Cell wall.

(c) Stage subsequent to the fragmentation of the membrane envelopes in an 8-day-old nodule formed by NA30 at $30^{\circ} \mathrm{C}$. Bacteria are free within the cytoplasm of the cell and are undergoing degeneration.

(d) A section of a cell showing the advanced stage of bacterial degeneration in a nodule formed by NA30 at $30{ }^{\circ} \mathrm{C}$. IS, Intercellular space; IT, infection thread. 

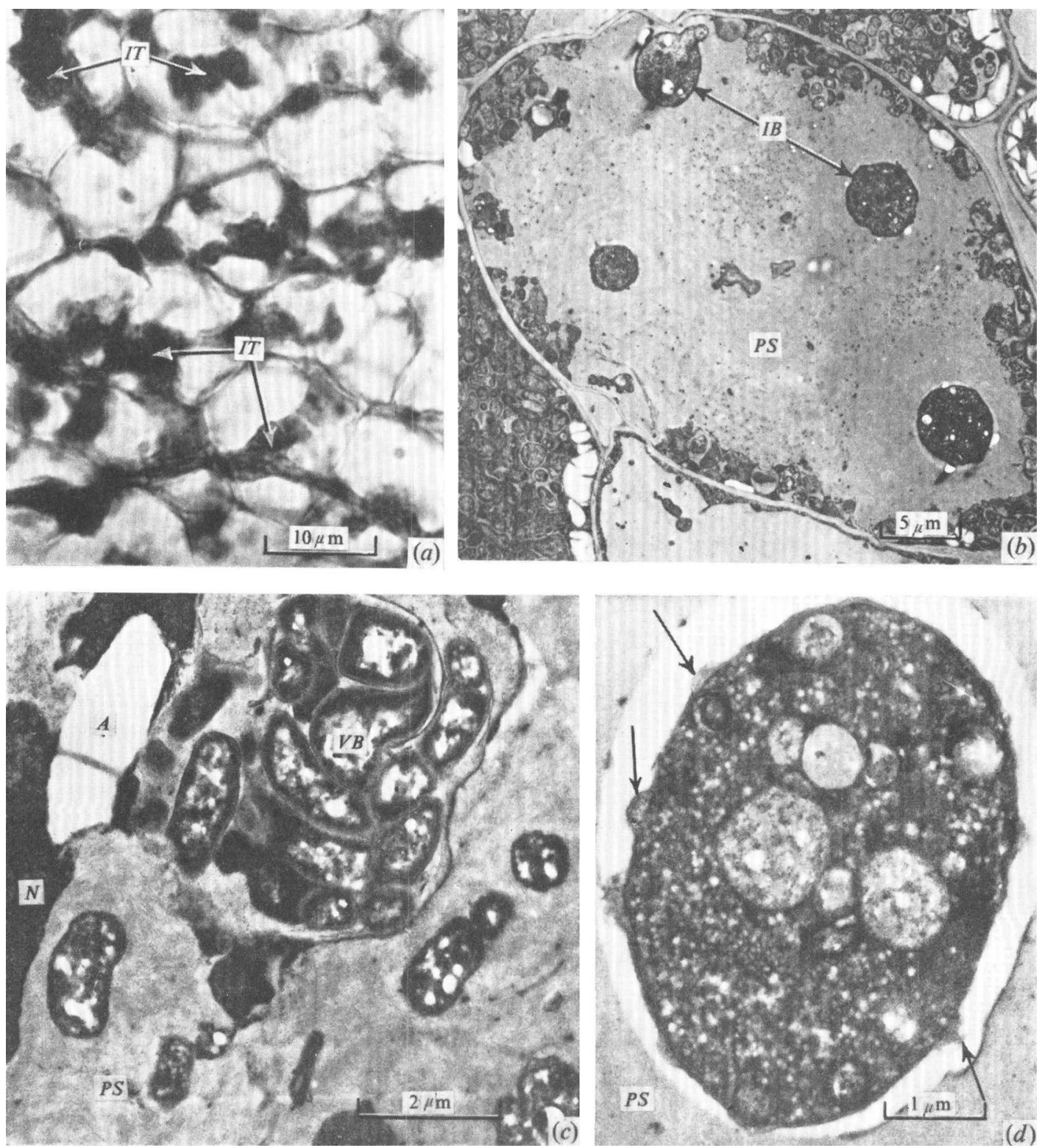

Fig. 4. (a) A light micrograph of cells in the region of infection thread penetration in a 10-day-old nodule formed by NA30 at $30^{\circ} \mathrm{C}$. Note the distorted and swollen nature of the numerous infection threads $(I T)$.

(b) A cell in an 8-day-old nodule formed by NA30 at $30^{\circ} \mathrm{C}$, containing an accumulation of material identified as polysaccharide $(P S)$ in light-microscope sections. Several bacteria occluded in this material are inflated to an abnormal size $(I B)$. Other bacteria enclosed in membrane envelopes are present between this material and the cell wall.

(c) A section of a cell in an 8-day-old nodule formed by NA30 at $30{ }^{\circ} \mathrm{C}$, showing what appears to be a ruptured infection thread containing vegetative bacteria $(V B)$ adjacent to the nucleus $(N)$. The bacteria from the thread remain occluded within polysaccharide-like material. $A$, Amyloplast.

(d) A section of an abnormally large bacterium occluded in polysaccharide-like material. The cell wall of the bacterium is distorted and ruptured in several places (see arrows). Large cellular inclusions, several of them membrane-bounded, are present in the bacterium. An electron-transparent region immediately surrounds the bacterium, separating it from the external polysaccharide (PS). 
Table I, Comparison of bacteria and membrane envelope profile areas in 8-day-old nodules formed by Rhizobium trifolii strains TAI and NA30 at 22 and $30^{\circ} \mathrm{C}$

Values based on data for 30 envelopes except for TAI $/ 30^{\circ} \mathrm{C}$ vegetative bacteria (I2 envelopes). Values in parentheses are standard errors.

$\begin{array}{lccccc}\begin{array}{c}\text { Bacterial } \\ \text { strain }\end{array} & \begin{array}{c}\text { Temperature } \\ \left({ }^{\circ} \mathrm{C}\right)\end{array} & \begin{array}{c}\text { Bacteroids } \\ \text { (no./envelope) }\end{array} & \begin{array}{c}\text { Vegetative } \\ \text { bacteria } \\ \text { (no./envelope) }\end{array} & \begin{array}{c}\text { Envelope } \\ \text { profile area } \\ \left(\mu \mathrm{m}^{2}\right)\end{array} & \begin{array}{c}\text { Bacteria } \\ \text { profile area } \\ \left(\mu \mathrm{m}^{2}\right)\end{array} \\ \text { NA30 } & 22 & 1 \cdot 0 & - & 4.27(0.75) & 3.40(0.90) \\ \text { TAI } & 22 & 1 \cdot 0 & - & 4.23(0.72) & 3.72(0.69) \\ \text { NA30 } & 30 & 1 \cdot 0 & - & 3.45(0.69) & 2.94(0.76) \\ & & - & 3.90(\mathrm{I} \cdot 29) & 3.74(1.07) & 0.49(0.27) \\ \text { TAI } & 30 & 1 \cdot 0 & - & 4.44(0.66) & 4.00(0.74) \\ & & - & 4.25(0.66) & 3.64(\mathrm{I} \cdot 09) & 0.43(0.24)\end{array}$

Nitrogenase activity and structure of nodules transferred between moderate and high temperatures

The acetylene-reducing activity of nodulated roots assayed at both 22 and $30^{\circ} \mathrm{C}$ showed little or no effect of assay incubation temperature, regardless of the strain forming the nodules. This indicated that the higher temperature was not affecting the nitrogen fixation process per se.

Plants grown at $22{ }^{\circ} \mathrm{C}$ were transferred to $30{ }^{\circ} \mathrm{C}$ root temperature $\mathrm{I} 2$ and $2 \mathrm{I}$ days after inoculation, and nitrogenase activity determined by the acetylene-reduction technique at regular intervals. Activity of NA30 nodules was maintained for 3 to 4 days (Fig. $6 a, b$ ) then fell rapidly to a low level. Upon transfer of these plants back to $22{ }^{\circ} \mathrm{C}$ after 6 days at $30^{\circ} \mathrm{C}$, only a small rise in activity was observed during the subsequent 4 days. The nitrogenase activity of TAI plants transferred to $30^{\circ} \mathrm{C}$ levelled off, whereas at $22^{\circ} \mathrm{C}$, it continued to rise. Return of TAI plants from 30 to $22{ }^{\circ} \mathrm{C}$ resulted in a dramatic but unexplained increase in activity 2 days later and a decline to a more normal level by the fourth day (Fig. 6a).

Table 2. Percentage degeneration of bacteroid tissue in nodules formed by Rhizobium trifolii strains TAI and NA30 following transfer from 22 to $30^{\circ} \mathrm{C}$ root temperature

Values are averages of median sections of five nodules. Values in parentheses are standard errors.

\begin{tabular}{llccc}
\multicolumn{1}{c}{ Treatment } & $\begin{array}{c}\text { Transferred } \\
\text { 12 days after } \\
\text { inoculation }\end{array}$ & \multicolumn{2}{c}{ Transferred 21 days after inoculation } \\
Days after transfer $\ldots$ & 4 & 3 & 4 & 6 \\
NA30 $22{ }^{\circ} \mathrm{C}$ control & 0 & 0 & $4 \cdot 8(\mathrm{I} \cdot 3)$ & $9 \cdot 4(4 \cdot 8)$ \\
NA30 $\quad$ Transferred & $25 \cdot 2(6 \cdot 4)$ & $12 \cdot 4(3 \cdot 5)$ & $37 \cdot 5(8 \cdot 8)$ & $49 \cdot 3(8 \cdot 9)$ \\
TA1 $22{ }^{\circ}$ C control & 0 & 0 & 0 & 0 \\
TA1 Transferred & 0 & 0 & $4 \cdot 5(1 \cdot 5)$ & $8 \cdot 8(7 \cdot 6)$
\end{tabular}

Transferring TAI plants grown at $22{ }^{\circ} \mathrm{C}$ to the higher root temperature $\left(30^{\circ} \mathrm{C}\right)$ produced no observable effect on nodule structure in 4 days except that starch deposits had commenced to diminish. After 6 days at $30^{\circ} \mathrm{C}$ degeneration of the bacteroids in the older cells had commenced (Table 2). Within the NA30 nodules the rapid breakdown and degeneration of host cells towards the base of the nodules was observed 3 days after transfer (Fig. $5 c, \mathrm{cf} .5 d$ ). By day 8 this breakdown was well advanced (Fig. 5 b). Nodules on NA30 plants transferred to $30{ }^{\circ} \mathrm{C}$ I 2 days after inoculation showed an average of $25 \%$ of the bacteroid tissue undergoing 

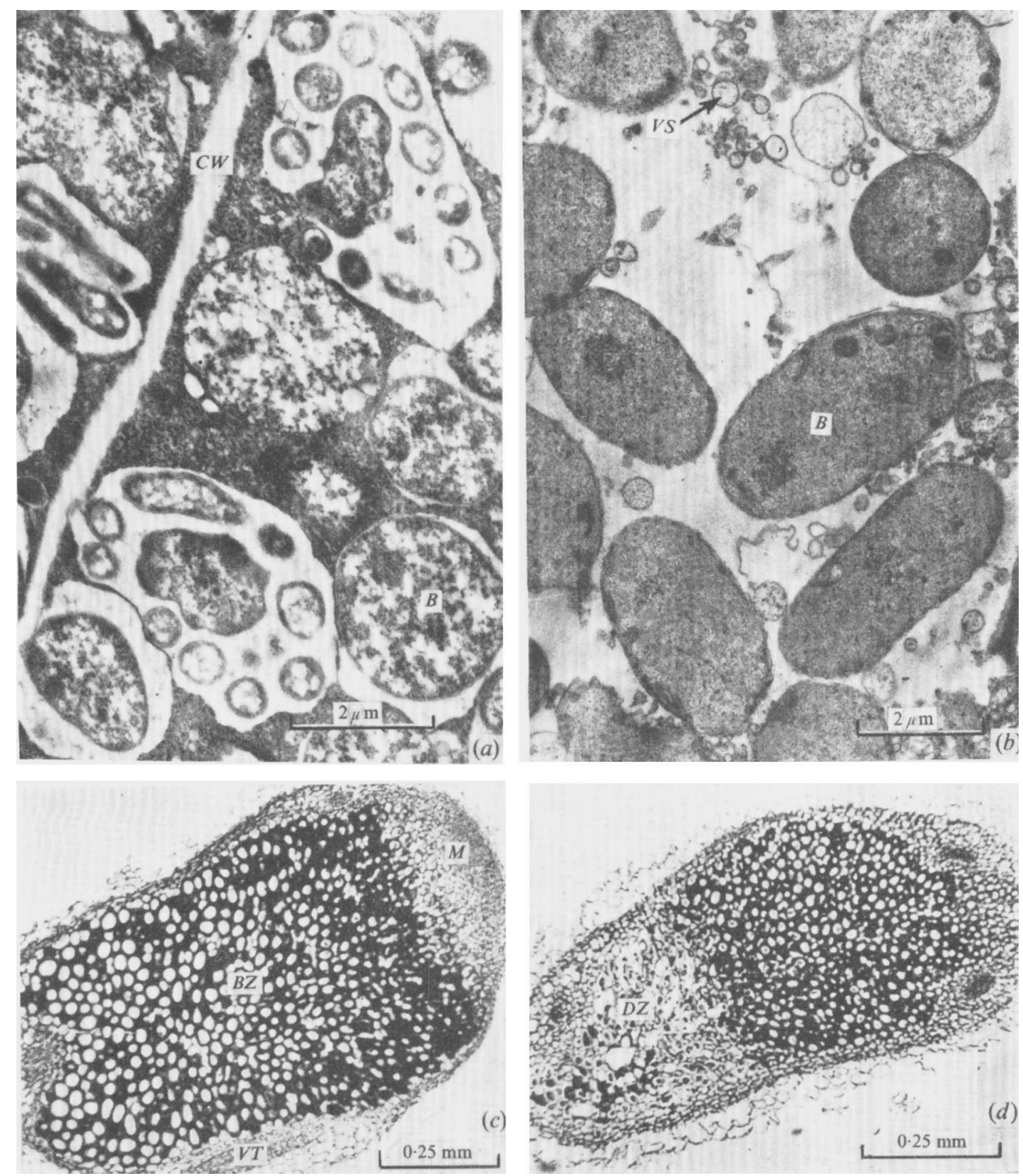

Fig. 5. (a) An 8-day-old nodule formed by TAI at $30^{\circ} \mathrm{C}$. Membrane envelopes containing six or more bacteria can be seen amongst normal bacteroids $(B)$, which individually occupy a membrane envelope. $C W$, Cell wall.

(b) A section of a cell undergoing degeneration in a 14-day-old nodule formed by NA3O at $22^{\circ} \mathrm{C}$ and exposed to $30{ }^{\circ} \mathrm{C}$ for four days. Note the numerous vesicles $(V S)$ and what appear to be fragments of membrane amongst the free bacteroids $(B)$. (Cf. Fig. $3 c, d$.)

(c) A longitudinal section of a 14-day-old nodule formed by NA30 at $22{ }^{\circ} \mathrm{C}$. $M$, Meristem; $B Z$, region of mature bacteroids.

(d) A longitudinal section of a 14 -day-old nodule formed by NA30 at $22{ }^{\circ} \mathrm{C}$ and exposed to $30{ }^{\circ} \mathrm{C}$ root temperature for 4 days (i.e. nodule ro days old when plant transferred from 22 to $30^{\circ} \mathrm{C}$ root temperature). Note the large region of the degeneration $(D Z)$ at the base of the nodule. (Cf. Fig. 5c.) 


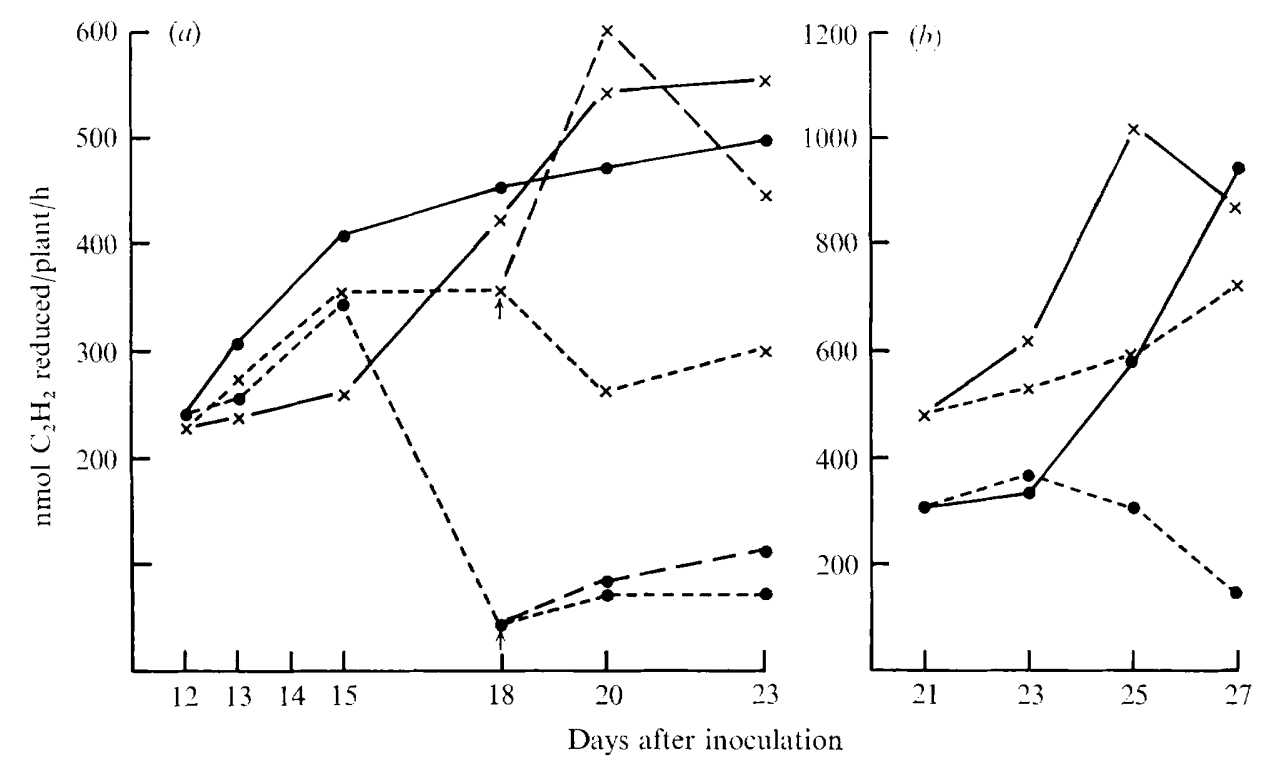

Fig. 6. Nitrogenase activity of Trifolium subterraneum plants inoculated with Rhizobium trifolii strains TAI $(x)$ and NA30 $(-)$ when grown continuously at $22{ }^{\circ} \mathrm{C}$ root temperature $(-)$ or transferred from 22 to $30^{\circ} \mathrm{C}$ root temperature (- -). Transfer to $30^{\circ} \mathrm{C}$ commenced I2 days (Fig. $6 a$ ) and 2I days (Fig. $6 b$ ) after inoculation, with some plants (Fig. $6 a$ ) being transferred back to $22{ }^{\circ} \mathrm{C}$ 6 days after the initial transfer to $30^{\circ} \mathrm{C}(--$, indicated by arrows). Activity determined by the acetylene-reduction technique.

degeneration 4 days after transfer, whilst in nodules on plants transferred to $30{ }^{\circ} \mathrm{C} 2 \mathrm{I}$ days after inoculation, $37 \%$ of the tissue was degenerating after 4 days (Table 2). The growth and branching of the infection threads immediately distal to the meristem of NA30 nodules was increased following transfer to $30^{\circ} \mathrm{C}$, and in newly invaded cells there was some bacterial division within the membrane envelopes by the third day following transfer.

\section{Effect of temperature on bacterial growth}

Following the observed multiplication of NA30 cells within the membrane envelopes at $30{ }^{\circ} \mathrm{C}$ the effect of temperature on the growth of strains TAI and NA3O was examined in liquid nutrient medium. Strain TAI had the higher growth rate at $22{ }^{\circ} \mathrm{C}$, but strain NA30 was superior at $30^{\circ} \mathrm{C}$ (Fig. 7); strain NA30 also had a higher growth rate than TA I at 28 and $34{ }^{\circ} \mathrm{C}$. Similar results were obtained at 22 and $30^{\circ} \mathrm{C}$ when twice the concentration of glucose, mannitol and glutamate were used in the medium.

\section{DISCUSSION}

There are three principal stages of development within the central tissue of young nodules. High root temperatures disrupt two of these stages in nodules formed by strain NA30 - the growth of the infection threads and the transformation of the bacterium in the envelopes into nitrogen-fixing bacteroids. Only the middle stage, the release of the bacteria from the infection thread and the initial formation of the envelopes, does not appear to be affected by the higher temperature. Whether the NA30 bacteria remain in the vegetative state within the envelopes, or commence development towards bacteroids could not be ascertained. There is no increase in size and the bacteria appear to continue in division until they disintegrate. Whilst 


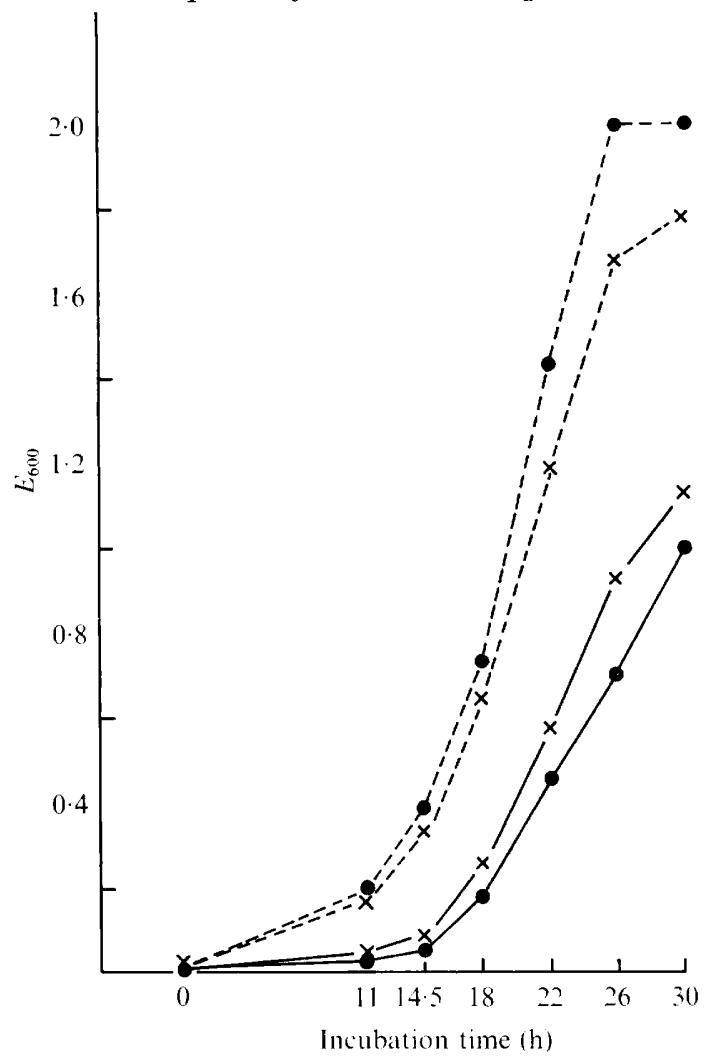

Fig. 7. Growth of Rhizobium trifolii strains TAI $(\times)$ and NA3O $(\bullet)$ when incubated in a rotary shaker at $22{ }^{\circ} \mathrm{C} \mathrm{(-)} \mathrm{and} 30^{\circ} \mathrm{C} \mathrm{(--)}$ in a yeast-extract medium (see Methods).

this does not preclude the initiation of nitrogenase development in these vegetative bacteria the low proportion of envelopes containing normal bacteroids would be sufficient to account for the low amount of nitrogen fixed. Within the TA I nodules only a small proportion of the envelopes have multiple occupancy of vegetative bacteria.

Clover nodules usually contain only one bacterium in each membrane envelope (Dart \& Mercer, 1963; Mosse, 1964; Dixon, 1967; Pankhurst, Schwinghamer \& Bergersen, 1972). Kidby \& Goodchild (I966) considered that the number of bacteria/envelope was hostcontrolled following observations made on effective nodules formed by one strain of Rhizobium lupini on Lupinus luteus L. (one bacteria/envelope) and Ornithopus sativus L. (two or more/envelope). In contrast, the differences observed in the present study are induced by temperature and are quantitatively different between bacterial strains. This suggests that the genetic mechanism controlling the conversion of the vegetative bacteria to bacteroids is suppressed at higher temperatures and that strain NA3O is more sensitive than strain TAI. That the suppression is not complete - some NA30 bacteria do transform into bacteroids suggests that micro-environmental conditions (physiological and physical) within the nodule can influence the metabolic changes occurring in the individual bacterium during its transformation into a bacteroid (Bergersen, 1958). Some indication of metabolic differences between strains TAI and NA3O is evident in the growth of the cultured bacteria (Fig 7). The higher growth rate of NA3O at the higher temperatures is particularly interesting.

The area of the membrane envelope profiles in the nodules initiated by each strain was 
similar, regardless of the temperature or whether bacteroids or vegetative bacteria occupy the space (Table I), which supports the conclusion of Kidby \& Goodchild (Ig66) that the development of the membrane envelope is under host control.

Some features of the NA30 nodules at $30^{\circ} \mathrm{C}$ are similar to observations made on the breakdown of nodules formed on plants deficient in boron (Brenchley \& Thornton, 1925) or transferred to the dark (Thornton, 1930). Thornton explained the degeneration as parasitism induced by the deficiency of available carbohydrate. However, the apparent presence of large quantities of polysaccharide in the host cell vacuoles makes this an unlikely explanation of the effect of high temperature.

The more rapid degeneration of the bacteroid tissue of developed NA30 nodules following transfer to $30^{\circ} \mathrm{C}$ indicates a further difference in the sensitivity of the two strains to higher temperature. That the tissue at the base of the nodules is first affected indicates that the effect is related to its physiological age, and to some extent is an accelerated form of the breakdown of Trifolium subterraneum nodule tissue growing at lower (I I to $19{ }^{\circ} \mathrm{C}$ ) root temperatures (Roughley, 1970). It is possible that the breakdown of nitrogenase is accelerated at $30{ }^{\circ} \mathrm{C}$ in NA30 bacteroids, relative to that in TAI bacteroids, or that under higher temperature conditions they are unable to replace nitrogenase broken down during the normal turnover of enzymes. The results with strains wU95 and CC2480 $a$ at 22 and $30^{\circ} \mathrm{C}$, and of a wide range of Rhizobium trifolii strains (Brockwell et al. 1968 ) indicate that the ability of strain TAI to develop an effective symbiosis at $30{ }^{\circ} \mathrm{C}$ is exceptional.

Host influence on nodulation, including failure to develop the characteristic bacteroid morphology, is well known in ineffective associations (Bergersen, 1957). Studies of genetic incompatibility between strains of rhizobia and their hosts (Nutman, I969) have concerned nodule development and structure under optimal growth conditions. The presently described breakdown of the symbiosis implicates an environmental factor in the regulation of normal nodule development.

The authors wish to thank Dr F. J. Bergersen for helpful discussions during the preparation of the manuscript and Miss Pauline Donlon for her valued technical assistance. One of us (C.E.P.) gratefully acknowledges the Department of Scientific and Industrial Research, New Zealand, for the provision of overseas leave, the Australian National University for a research scholarship and the Commonwealth Scientific and Industrial Research Organization for the provision of research facilities.

\section{REFERENCES}

Bergersen, F. J. (1957). The structure of ineffective root nodules of legumes : an unusual new type of ineffectiveness, and an appraisal of present knowledge. Australian Journal of Biological Sciences ro, 223-242.

Bergersen, F. J. (1958). The bacterial component of soybean root nodules: changes in respiratory activity, cell dry weight and nucleic acid content with increasing nodule age. Journal of General Microbiology $\mathbf{1 9}$, 312-323.

Bergersen, F. J. (1961). The growth of Rhizobium in synthetic media. Australian Journal of Biological Sciences I4, 349-360.

Bergersen, F. J. (1970). The quantitative relationship between nitrogen fixation and the acetylene-reduction assay. Australian Journal of Biological Sciences 23, $1015-1025$.

Brenchley, W. E. \& Thornton, H. G. (1925). The relation between the development, structure and functioning of the root nodules on Vicia faba as influenced by the presence or absence of boron in the nutrient medium. Proceedings of the Royal Society of London B 98, 373-399.

Brockwell, J., Dudman, W. F., Gibson, A. H., Hely, F. W. \& Robinson, A. C. (I968). An integrated programme for the improvement of legume inoculant strains. Transactions of the 9 th International Congress of Soil Science, vol. 2, pp. I03-I I4. 
DarT, P. J. \& Mercer, F. V. (1963). Development of the bacteroid in the root nodule of barrel medic (Medicago tribuloides Desr.) and subterraneum clover (Trifolium subterraneum L.). Archiv für Mikrobiologie 46, 382-40r.

DART, P. J. \& MERCER, F. V. (I965). The effect of growth temperature, level of ammonium nitrate, and light intensity on the growth and nodulation of cowpea (Vigna sinensis Endl. ex Hassk.). Australian Journal of Agricultural Research 16, 321-345.

Dixon, R. O. D. (1967). The origin of the membrane envelope surrounding the bacteria and bacteroids and the presence of glycogen in clover root nodules. Archiv fiir Mikrobiologie 56, 156-166.

Feder, N. \& O'Brien, T. P. (1968). Plant microtechnique: some principles and new methods. American Journal of Botany 55, $123-142$.

Girson, A. H. (1963). Physical environment and symbiotic nitrogen fixation. I. The effect of root temperature on recently nodulated Trifolium subterraneum L. plants. Australian Journal of Biological Sciences 16, $28-42$.

Gibson, A. H. (1965). Physical environment and symbiotic nitrogen fixation. II. Root temperature effects on the relative nitrogen assimilation rate. Australian Journal of Biological Sciences 18, 295-3 10.

Gibson, A. H. (1967). Physical environment and symbiotic nitrogen fixation. V. Effect of time of exposure to unfavorable root temperatures. Australian Journal of Biological Sciences 20, I I05-I I 7.

Gibson, A. H. (1969). Physical environment and symbiotic nitrogen fixation. VII. Effect of fluctuating root temperature on nitrogen fixation. Australian Journal of Biological Sciences 22, 839-846.

GiBson, A. H. (1971). Factors in the physical and biological environment affecting nodulation and nitrogen fixation by legumes. In Biological Nitrogen Fixation in Natural and Agricultural Habitats. Plant and Soil, special volume, pp. I 39-I52. Edited by T. A. Lie and E. G. Mulder. The Hague: Nijhoff.

GoodChILD, D. J. \& BeRGersen, F. J. (1966). Electron microscopy of the infection and subsequent development of soybean nodule cells. Journal of Bacteriology 92, 204-2 I 3.

Hardy, R. W. F., Holsten, R. D., Jackson, E. K. \& BURNs, R. C. (1968). The acetylene-ethylene assay for $\mathrm{N}_{2}$ fixation: laboratory and field evaluation. Plant Physiology 43, I I 85-1207.

Jensen, W. A. (1962). Botanical Histochemistry: Principles and Practice. San Francisco and London: W. H. Freeman.

KiDBY, D. K. \& GoodChILD, D. J. (1966). Host influence on the ultra structure of root nodules of Lupinus luteus and Ornithopus sativus. Journal of General Microbiology 45, I47-1 52.

Mosse, B. (1964). Electron-microscope studies of nodule development in some clover species. Journal of General Microbiology 36, 49-66.

Nutman, P.S. (1969). Genetics of symbiosis and nitrogen fixation in legumes. Proceedings of the Royal Society B 172, 417-437.

Pankhurst, C. E., Schwinghamer, E. A. \& Bergersen, F. J. (1972). The structure and acetylene-reducing activity of root nodules formed by a riboflavin-requiring mutant of Rhizobium trifolii. Journal of General Microbiology 70, I6I-I77.

Roughley, R. J. (1970). The influence of root temperature, Rhizobium strain and host selection on the structure and nitrogen fixing efficiency of the root nodules of Trifolium subterraneum. Annals of Botany $34,63 \mathrm{I}-646$.

THORNTON, H. G. (1930). The influence of the host plant in inducing parasitism in lucerne and clover nodules. Proceedings of the Royal Society B ro6, I $10-122$. 